\title{
Pengaruh Jenis Pelarut dan Ukuran Partikel Bahan terhadap Karakteristik Ekstrak Daun Bidara (Ziziphus mauritiana L.) sebagai Sumber Saponin
} The Influence of Solvent Type and Particle Size of Materials Againts on The Characteristics Bidara Leaf Extract (Ziziphus Mauritiana L.) as A Source of Saponins

Ika Martoquito Lumbanraja, Ni Made Wartini*, Lutfi Suhendra

PS Teknologi Industri Pertanian, Fakultas Teknologi Pertanian, Universitas Udayana, Kampus Bukit Jimbaran, Badung, Kode pos : 80361; Telp/Fax : (0361) 701801.

Diterima 17 Juli 2019 / Disetujui 07 Agustus 2019

\begin{abstract}
Bidara (Ziziphus mauritiana L.) is widely grown in the tropics. Bidara is rich in benefits because it has content of saponins contained in the leaves. Saponins compounds derived plants can be used as soap foaming agents. Saponins can be applied in the manufacture of soap because of its nature as a natural surfactant. The purpose of this study were to determine the influence of solvent type and particle size of materials againts on the characteristics bidara leaf extract as a source of saponins, get the best solvent type and particle size to produce bidara leaf extract as a source of saponins. This study used a Randomized Block Design with treatment of solvent type and particle size of materials. Treatment of solvent type consists of 3 levels, namely: methanol, ethanol and acetone. The particle size of materials treatment also consists of 3 levels, namely: 40 mesh, 60 mesh and 80 mesh. Each treatment are grouped into two-based implementation. The results showed that treatment of solvent type and particle size of materials very significant effect on yield, coarse extract saponins content and foam height leaves bidara as a source of saponins. Interaction between treatments very significant effect on yield and foam height. However, significant effect on coarse extract saponins content bidara leaves. The methanol solvent type treatment with particle size of material 80 mesh is the best treatment to produce bidara leaf extract as a source of saponins with value yield of $17.91 \pm 0.73 \%, 20.40 \pm 0.79 \%$ coarse extract saponins content and foam height of $8.27 \pm 0.01 \mathrm{~mm}$.
\end{abstract}

Keywords : Ziziphus mauritina L., saponins, extraction, solvent type, the particle size of material.

*Korespondensi Penulis:

Email : md_wartini@unud.ac.id 


\section{PENDAHULUAN}

Indonesia memiliki beranekaragam tanaman yang dapat dimanfaatkan sebagai sumber saponin. Salah satu jenis tanaman yang dapat digunakan sebagai sumber saponin ialah tanaman bidara (Safrudin dan Fitri, 2018). Tanaman bidara (Ziziphus mauritiana L.) banyak tumbuh liar di daerah Jawa, Bali dan Nusa Tenggara Barat (Heyne, 1987). Tanaman bidara kaya akan manfaat karena memiliki kandungan saponin triterpen yang terdapat pada bagian daunnya (Michel et al., 2011). Hal tersebut telah terbukti sesuai dengan penelitian yang dilakukan oleh (Bintoro et al., 2017) menyatakan bahwa tanaman bidara mengandung senyawa saponin triterpen yang diidentifikasi melalui uji warna. Penambahan pereaksi Lieberman Burchard (LB) pada simplisia daun bidara menghasilkan cincin berwarna cokelat keunguan yang menujukkan bahwa terdapat saponin triterpen (Farnsworth, 1966).

Saponin merupakan golongan senyawa glikosida yang mempunyai rasa sepat dan memiliki aktivitas antibakteri (Novitasari dan Dinda, 2016). Berdasarkan aglikonnya saponin terdiri dari dua jenis yaitu saponin steroid dan saponin triterpen. Senyawa saponin mudah larut dalam air dan memiliki karakteristik berupa buih, sehingga ketika digojog dengan air akan terbentuk buih yang stabil (Suharto et al., 2012). Kemampuan saponin membentuk buih dikarenakan kombinasi struktur senyawa penyusunnya yaitu rantai gula yang bersifat hidrofilik dan bagian rantai sapogenin yang bersifat hidrofobik (Jaya, 2010). Hal tersebut yang menyebabkan saponin disebut sebagai surfaktan alami (Calabria, 2008).

Senyawa saponin menjadi penting karena dapat digunakan sebagai bahan pembusa sabun (Vincken et al., 2007). Penggunaan saponin alami sebagai pembusa sabun membuat sabun menjadi lebih ramah lingkungan dan tidak memerlukan penambahan foam booster yang merupakan senyawa sintetis (Mandal, 2005). Penambahan saponin ke sabun, shampoo, deterjen cair dan pasta gigi membuat busa pada produk tersebut menjadi tahan lama. Hal tersebut dikarenakan, surfaktan alami seperti saponin memiliki kestabilan busa yang cukup besar yaitu sekitar 86\% (Chen et al., 2010). Akan tetapi, saat ini saponin alami yang berasal dari tumbuhan belum banyak dimanfaatkan sebagai pembusa sabun seperti halnya saponin dari tanaman bidara.

Senyawa saponin yang terkandung di daun bidara dapat diperoleh melalui proses ekstraksi. Ekstraksi dilakukan dengan metode maserasi menggunakan pelarut (Bintoro et al., 2017). Metode maserasi digunakan karena merupakan salah satu metode ekstraksi yang paling mudah dilakukan (Pratiwi, 2010). Proses ekstraksi saponin dipengaruhi oleh beberapa faktor diantaranya jenis pelarut yang digunakan, ukuran partikel bahan, suhu, lama ekstraksi, perbandingan bahan dengan pelarut dan metode ekstraksi. Faktor-faktor tersebut sangat mempengaruhi tingkat keberhasilan dari proses ekstraksi yang dilakukan dan hasil ekstrak saponin yang diperoleh.

Permasalahan yang dihadapi dalam proses ekstraksi saponin daun bidara ialah belum diketahui jenis pelarut dan ukuran partikel bahan yang sesuai untuk menghasilkan ekstrak saponin tertinggi. Ekstrak saponin akan lebih banyak dihasilkan jika diekstrak menggunakan pelarut polar, karena saponin bersifat hidrofilik (Harborne, 1987). Hal tersebut sesuai dengan penelitian yang dilakukan oleh Pham et al. (2015) menyatakan bahwa pelarut metanol menghasilkan kadar saponin lebih tinggi dibandingkan dengan pelarut etanol, etil asetat dan air pada daun Helicteres hirsuta $\mathrm{L}$. yaitu sebesar $35 \mathrm{mgESE} / \mathrm{g}$. Akan tetapi, penggunaan air sebagai pelarut kurang efektif digunakan karena air dapat menyebabkan kerusakan pada bahan aktif menjadi lebih 
cepat, terjadi pembengkakan sel dan larutan mudah terkontaminasi oleh mikroorganisme (Hardiningtyas, 2009). Berbeda dengan penelitian yang dilakukan oleh Ngo et al. (2017) menyatakan bahwa pelarut aseton menghasilkan kadar saponin lebih tinggi dibandingkan dengan pelarut metanol dan etanol pada akar Salacia chinensis L. yaitu sebesar $754 \mathrm{mgESE} / \mathrm{g}$. Oleh sebab itu, pelarut yang digunakan pada penelitian ini ialah metanol, etanol dan aseton.

Ukuran partikel bahan yang digunakan juga mempengaruhi proses ekstraksi yang dilakukan. Ukuran partikel bahan yang semakin kecil cenderung memudahkan pelarut untuk mengekstrak senyawa aktif yang terdapat pada bahan. Hal tersebut dikarenakan, semakin kecil ukuran partikel bahan menyebabkan semakin banyak sel yang rusak sehingga memudahkan pelarut untuk menarik senyawa fitokimia dari bahan (Ketaren, 1986). Hal tersebut sesuai dengan penelitian yang dilakukan oleh Antari (2015) menyatakan bahwa ukuran partikel 60 mesh menghasilkan rendemen lebih tinggi dibandingkan ukuran partikel 40 mesh yaitu sebesar $4,80 \%$. Sedangkan berdasarkan penelitian yang dilakukan oleh Manoi (2015) menyatakan bahwa ukuran partikel 40 mesh menghasilkan rendemen lebih tinggi dibandingkan ukuran partikel 20 dan 60 mesh yaitu berkisar $6,8-9,1 \%$. Oleh karena itu, ukuran partikel bahan yang digunakan pada penelitian ini ialah 40, 60 dan 80 mesh. Berdasarkan pemaparan tersebut, maka penelitian mengenai pengaruh jenis pelarut dan ukuran partikel bahan terhadap karakteristik ekstrak daun bidara sebagai sumber saponin perlu dilakukan.

Tujuan dari penelitian ini ialah untuk mengetahui pengaruh jenis pelarut dan ukuran partikel bahan terhadap karakteristik ekstrak daun bidara serta mendapatkan jenis pelarut dan ukuran partikel terbaik untuk menghasilkan ekstrak daun bidara sebagai sumber saponin.

\section{METODE PENELITIAN}

\section{Tempat dan Waktu Penelitian}

Penelitian ini dilakukan di Laboratorium Biokimia dan Nutrisi, Laboratorium Analisis Pangan, Laboratorium Pengolahan Pangan, Laboratorium Rekayasa Proses dan Pengendalian Mutu Fakultas Teknologi Pertanian, Universitas Udayana. Waktu pelaksanaan penelitian dimulai pada Maret-Mei 2019.

\begin{abstract}
Alat
Alat yang digunakan pada penelitian ini ialah loyang, blender (Miyako), ayakan 80, 60, 40 mesh (Retsch), timbangan analitik (Shimadzu), oven (Memmert), Erlenmeyer (Pyrex), gelas ukur (Pyrex), tabung reaksi (Pyrex), gelas beaker (Pyrex), pipet tetes, corong, sudip, kertas saring kasar, kertas saring Whatman No.1, aluminium foil, soxhlet (Sibron), vortex (Maxi mix), magnetic stirrer (Dlab), rotary evaporator vacuum (IKA), mikrometer sekrup, kertas label dan botol.
\end{abstract}

\section{Bahan}

Bahan baku yang digunakan pada penelitian ini ialah daun bidara (Ziziphus mauritiana L.) dengan kriteria daun berwarna hijau muda yang diambil daun pertama sampai ke enam dari pucuk diperoleh dari daerah Bukit Jimbaran. Bahan kimia yang digunakan ialah $\mathrm{HCl}$, aquades, pelarut teknis (Bratachem) untuk maserasi yaitu metanol $86 \%$, etanol $96 \%$, aseton $90 \%$ dan pelarut E. Merck untuk analisa yaitu petroleum eter, etil asetat, n-butanol, metanol serta dietil eter.

\section{Rancangan Percobaan}

Rancangan percobaan yang digunakan ialah Rancangan Acak Kelompok (RAK). Percobaan ini merupakan percobaan faktorial dengan dua faktor. Faktor pertama ialah jenis pelarut $(\mathrm{P})$ yang terdiri dari tiga level, yaitu: P1 : Metanol 86\%, P2 : Etanol 96\% dan P3 : 
Aseton 90\%. Faktor kedua ialah ukuran partikel bahan (S) yang terdiri dari tiga level, yaitu: S1 : 40 mesh, S2 : 60 mesh dan S3 : 80 mesh.

Berdasarkan kedua faktor diatas diperoleh 9 kombinasi perlakuan, yang masing-masing perlakuan diulang sebanyak 2 kali berdasarkan waktu pelaksanaannya, sehingga diperoleh 18 unit percobaan. Data obyektif yang diperoleh dianalisis dengan Analysis of Variance (ANOVA) dan apabila terdapat pengaruh perlakuan terhadap parameter yang diamati, maka dilanjutkan dengan uji Beda Nyata Jujur (BNJ). Perlakuan terbaik ditentukan dengan perlakuan yang menghasilkan rendemen tertinggi, kadar saponin kasar tertinggi dan ketinggian busa tertinggi.

\section{Pelaksanaan Penelitian}

Daun bidara (Ziziphus mauritiana L.) yang digunakan ialah daun bidara dengan kriteria daun berwarna hijau muda yang diambil daun pertama sampai ke enam dari pucuk (Sen et al., 1998). Selanjutnya, daun bidara yang diperoleh dibersihkan terlebih dahulu untuk menghilangkan kotorankotoran yang terdapat pada daun. Kemudian, ditiriskan dan dikeringkan menggunakan oven pada suhu $50 \pm 2^{\circ} \mathrm{C}$ selama 4 jam sampai daun bidara mudah dihancurkan. Selanjutnya, dihancurkan menggunakan blender agar didapatkan serbuk daun bidara.

Serbuk tersebut diayak menggunakan ayakan 80, 60 dan 40 mesh. Serbuk daun bidara yang sudah diayak ditimbang sebanyak 50 gram, kemudian dimasukkan ke erlenmeyer dan ditambahkan pelarut sesuai perlakuan (metanol 86\%, etanol $96 \%$ dan aseton 90\%) sebanyak $300 \mathrm{ml}$ (perbandingan bahan dengan pelarut 1:6). Erlenmeyer ditutup dengan aluminium foil dan dilakukan proses maserasi selama 48 jam pada suhu kamar, sambil sampel digojog setiap 12 jam selama 5 menit, sehingga nantinya diperoleh ekstrak daun bidara yang masih bercampur pelarut. Selanjutnya, dilakukan proses penyaringan menggunakan kertas saring kasar yang menghasilkan filtrat I dan ampas.

Filtrat yang diperoleh (filtrat I) ditampung, sedangkan ampas yang dihasilkan dibilas menggunakan pelarut sesuai perlakuan (metanol $86 \%$, etano $96 \%$ dan aseton 90\%) sebanyak 50 ml. Kemudian, digojog selama 5 menit dan disaring kembali menggunakan kertas saring kasar sehingga diperoleh filtrat II. Hasil filtrat I dan II dicampur. Selanjutnya, disaring menggunakan kertas saring Whatman No.1. Filtrat yang diperoleh selanjutnya dievaporasi menggunakan rotary evaporator vacuum pada suhu $40^{\circ} \mathrm{C}$ dengan tekanan 100 mBar. Proses evaporasi dihentikan pada saat semua pelarut sudah habis menguap sehingga diperoleh ekstrak kental. Esktrak kental yang diperoleh dimasukkan ke botol sampel dan diberi label (Modifikasi Bintoro et al., 2017; Yulianingtyas dan Bambang, 2016).

\section{Variabel yang Diamati}

Variabel yang diamati pada penelitian ini ialah rendemen ekstrak daun bidara, kadar ekstrak saponin kasar dan ketinggian busa.

\section{Rendemen (AOAC, 1999)}

Rendemen ekstrak daun bidara dihitung dengan cara, berat ekstrak daun bidara yang diperoleh dibagi dengan berat serbuk daun bidara yang digunakan, kemudian dikalikan $100 \%$. Rumus perhitungan untuk mencari rendemen dapat dilihat di bawah ini :

$$
\begin{gathered}
\text { Rendemen }(\%)=\frac{\text { Berat ekstrak daun bidara }(\mathrm{g})}{\text { Berat serbuk daun bidara }(\mathrm{g})} \times \\
100 \%
\end{gathered}
$$

\section{Kadar Ekstrak Saponin Kasar (Modifikasi Mien et al., 2015)}

Penetapan kadar ekstrak saponin daun bidara dilakukan dengan uji gravimetri, yaitu dengan cara ekstrak kental yang diperoleh ditimbang sebanyak 0,25 gram. Kemudian, 
ekstrak kental dilarutkan dengan petroleum eter sebanyak $10 \mathrm{ml}$ sambil sampel digojog menggunakan magnetic stirrer. Selanjutnya, direfluks selama 15 menit pada suhu 60$80^{\circ} \mathrm{C}$. Setelah dingin larutan petroleum eter dibuang dan residu yang tertinggal dilarutkan kembali dengan $10 \mathrm{ml}$ etil asetat sambil sampel digojog menggunakan magnetic stirrer. Kemudian, residu dipisahkan dari larutan etil asetat menggunakan kertas saring kasar.

Residu yang tertinggal dilarutkan kembali dengan n-butanol sebanyak $10 \mathrm{ml}$ dan larutan tersebut diuapkan menggunakan rotary evaporator vacuum. Residu yang tertinggal dilarutkan dengan metanol sebanyak $2 \mathrm{ml}$, kemudian larutan tersebut diteteskan ke dalam $10 \mathrm{ml}$ dietil eter sambil diaduk. Endapan yang terbentuk dalam campuran dituang ke kertas saring Whatman No.1 yang telah diketahui bobotnya. Endapan di atas kertas saring Whatman No.1 dikeringkan menggunakan oven pada suhu $40 \pm 2^{\circ} \mathrm{C}$ selama \pm 10 menit. Kemudian, kertas saring ditimbang sampai diperoleh bobot konstan. Selisih bobot kertas saring sebelum dan sesudah penguapan pelarut dari endapan ditetapkan sebagai bobot saponin. Rumus perhitungan untuk mencari kadar saponin dapat dilihat di bawah ini :

$$
\text { Kadar saponin }=\frac{\mathrm{X} 2-\mathrm{X} 1}{\mathrm{~A}} \times 100 \%
$$

Keterangan :

$\mathrm{X} 1$ = bobot kertas saring $(\mathrm{g})$
$\mathrm{X} 2$ = bobot kertas saring + endapan saponin

(g)

$\mathrm{A}=$ bobot ekstrak daun bidara (g)

Uji Busa (Modifikasi Bintoro et al., 2017)

Uji busa dilakukan untuk menghitung ketinggian busa yang terbentuk pada sampel yang diamati. Uji busa dilakukan dengan cara, residu saponin dari hasil pengukuran ekstrak saponin kasar yang tertinggal di kertas saring ditimbang sebanyak 0,03 gram. Kemudian, dimasukkan ke tabung reaksi yang telah berisi aquades sebanyak $10 \mathrm{ml}$. Larutan tersebut digojog selama 10 detik hingga terbentuk buih yang stabil. Selanjutnya, ditambahkan larutan $\mathrm{HCl} 2 \mathrm{~N}$ sebanyak 1 tetes melalui dinding tabung reaksi. Kemudian, diukur ketinggian busa yang terbentuk pada sampel menggunakan mikrometer sekrup. Pengukuran dilakukan sebanyak 3 kali di waktu yang berbeda untuk memperoleh hasil pengukuran yang akurat. Kemudian, hasil pengukuran tersebut dijumlahkan untuk mendapatkan rerata yang ditetapkan sebagai ketinggian busa.

\section{HASIL DAN PEMBAHASAN}

\section{Rendemen Ekstrak}

Hasil sidik ragam menunjukkan bahwa perlakuan jenis pelarut, ukuran partikel bahan dan interaksi antar perlakuan berpengaruh sangat nyata $(\mathrm{P}<0,01)$ terhadap rendemen ekstrak. Nilai rata-rata rendemen ekstrak daun bidara dapat dilihat pada Tabel 1 .

Tabel 1. Nilai rata-rata rendemen ekstrak (\%)

\begin{tabular}{llll}
\hline \multirow{2}{*}{ Jenis Pelarut $(\mathbf{P})$} & \multicolumn{4}{l}{ Ukuran Partikel (S) } \\
\cline { 2 - 4 } & S1 $(40$ mesh) & S2 $(60$ mesh $)$ & S3 $(80$ mesh) \\
\hline P1 (Metanol) & $13,14 \pm 0,01^{\mathrm{c}}$ & $15,51 \pm 0,30^{\mathrm{b}}$ & $17,91 \pm 0,73^{\mathrm{a}}$ \\
P2 (Etanol) & $6,14 \pm 0,08^{\mathrm{f}}$ & $8,23 \pm 0,21^{\mathrm{e}}$ & $10,48 \pm 0,52^{\mathrm{d}}$ \\
P3 (Aseton) & $2,12 \pm 0,05^{\mathrm{h}}$ & $3,66 \pm 0,18^{\mathrm{g}}$ & $4,20 \pm 0,03^{\mathrm{g}}$ \\
\hline
\end{tabular}

Keterangan : Huruf berbeda di belakang nilai rata-rata menunjukkan perbedaan yang sangat nyata pada taraf kesalahan $1 \%(\mathrm{P}<0,01)$.

Tabel 1 menunjukkan bahwa jenis pelarut metanol dengan ukuran partikel bahan
80 mesh menghasilkan nilai rata-rata

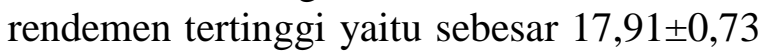


persen sedangkan jenis pelarut aseton dengan ukuran partikel bahan 40 mesh menghasilkan nilai rata-rata rendemen terendah yaitu sebesar 2,12 $\pm 0,05$ persen. Tabel 1 menunjukkan bahwa semakin polar pelarut yang digunakan dan semakin kecil ukuran partikel bahan, maka semakin banyak senyawa dalam daun bidara yang terekstrak. Hal ini dikarenakan senyawa yang terkandung dalam daun bidara cenderung bersifat polar sehingga lebih banyak larut dalam pelarut metanol. Gillespie et al. (2001) menyatakan bahwa konstanta dielektrik pelarut sangat berpengaruh terhadap daya larut. Pelarut metanol memiliki nilai konstanta dielektrik yang lebih tinggi yaitu sebesar 33,62, sehingga pelarut metanol lebih bersifat polar (Sumardji et al., 1997).

Darma et al. (1991) menyatakan bahwa penggunaan pelarut yang semakin polar cenderung lebih mudah larut dalam bahan dengan ukuran partikel yang semakin kecil. Hal tersebut dikarenakan, semakin kecil ukuran partikel bahan menyebabkan semakin banyak sel yang rusak sehingga memudahkan pelarut untuk menembus dinding sel dan menarik senyawa aktif dari bahan Ketaren (1986). Hal tersebut didukung oleh penelitian sebelumnya yang dilakukan oleh Pasaribu et al. (2014) mengenai pengaruh ukuran partikel dan jenis pelarut terhadap kandungan saponin dari ekstrak kulit buah Sapindus rarak. Hasil yang diperoleh menunjukkan bahwa jenis pelarut metanol menghasilkan rendemen saponin sebesar 35,98 persen dan ukuran partikel bahan 200 mesh menghasilkan rendemen saponin sebesar 43,52 persen. Hal ini sesuai dengan penelitian yang telah dilakukan bahwa penggunaan pelarut yang semakin polar dan ukuran partikel yang semakin kecil menyebabkan semakin tinggi rendemen saponin yang dihasilkan, karena pelarut metanol dan ukuran partikel bahan 80 mesh adalah yang paling efektif digunakan untuk menarik senyawa fitokimia dari daun bidara.

\section{Kadar Ekstrak Saponin Kasar}

Hasil sidik ragam menunjukkan bahwa perlakuan jenis pelarut dan ukuran partikel bahan berpengaruh sangat nyata $(\mathrm{P}<0,01)$, sedangkan interaksi antar perlakuan berpengaruh nyata $(\mathrm{P}<0,05)$ terhadap kadar ekstrak saponin kasar daun bidara. Nilai ratarata kadar esktrak saponin kasar daun bidara dapat dilihat pada Tabel 2.

Tabel 2. Nilai rata-rata kadar ekstrak saponin kasar (\%)

\begin{tabular}{lccc}
\hline \multirow{2}{*}{ Jenis Pelarut $(\mathbf{P})$} & \multicolumn{3}{c}{ Ukuran Partikel (S) } \\
\cline { 2 - 4 } & S1 $(40$ mesh) & S2 $(60$ mesh) & S3 $(80$ mesh) \\
\hline P1 (Metanol) & $15,23 \pm 0,15^{\mathrm{c}}$ & $18,47 \pm 0,01^{\mathrm{b}}$ & $20,40 \pm 0,79^{\mathrm{a}}$ \\
P2 (Etanol) & $8,11 \pm 0,67^{\mathrm{f}}$ & $10,02 \pm 0,45^{\mathrm{e}}$ & $13,27 \pm 0,07^{\mathrm{d}}$ \\
P3 (Aseton) & $3,01 \pm 0,16^{\mathrm{i}}$ & $4,69 \pm 0,35^{\mathrm{h}}$ & $6,42 \pm 0,13^{\mathrm{g}}$ \\
\hline
\end{tabular}

Keterangan : Huruf berbeda di belakang nilai rata-rata menunjukkan perbedaan yang nyata pada taraf kesalahan $5 \%(\mathrm{P}<0,05)$.

Tabel 2 menunjukkan bahwa jenis pelarut metanol dengan ukuran partikel bahan 80 mesh menghasilkan rata-rata kadar esktrak saponin kasar daun bidara tertinggi yaitu sebesar 20,40 $\pm 0,79$ persen sedangkan jenis pelarut aseton dengan ukuran partikel bahan 40 mesh menghasilkan rata-rata kadar esktrak saponin kasar daun bidara terendah yaitu

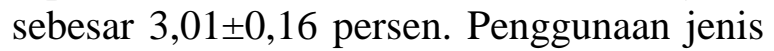

pelarut dan ukuran partikel bahan yang berbeda saat proses ekstraksi sangat mempengaruhi kadar saponin yang dihasilkan. Hal ini menunjukkan bahwa semakin polar pelarut yang digunakan dan semakin kecil ukuran partikel bahan, maka semakin tinggi kadar saponin yang dihasilkan. Hal tersebut dikarenakan ekstrak saponin yang terdapat pada daun bidara 
memiliki tingkat kepolaran yang mendekati kepolaran pelarut metanol, sehingga pelarut metanol lebih mudah larut daripada pelarut etanol dan aseton (Pham et al,. 2015).

Sesuai dengan pernyataan Vogel (1978) yang menyatakan bahwa polaritas suatu pelarut sangat berpengaruh terhadap daya larut. Semakin polar pelarut yang digunakan cenderung akan lebih mudah larut dalam bahan dengan ukuran partikel yang semakin kecil. Hal tersebut dikarenakan, semakin kecil ukuran partikel bahan menyebabkan semakin banyak sel yang rusak sehingga memudahkan pelarut untuk menembus dinding sel dan menarik senyawa aktif dari bahan (Ketaren, 1986). Hal tersebut sesuai dengan penelitian sebelumnya yang dilakukan oleh Pasaribu et al. (2014) mengenai pengaruh ukuran partikel dan jenis pelarut terhadap kandungan saponin dari ekstrak kulit buah Sapindus rarak. Hasil yang diperoleh menunjukkan bahwa jenis pelarut metanol menghasilkan total saponin sebesar 30,55 persen dan ukuran partikel bahan 200 mesh menghasilkan total saponin sebesar 35,51 persen. Hal ini sesuai dengan penelitian yang telah dilakukan bahwa penggunaan pelarut yang semakin polar dan ukuran partikel yang semakin kecil menyebabkan semakin tinggi kadar saponin yang dihasilkan, karena kontak antara bahan dengan pelarut semakin efektif sehingga mempunyai kesempatan melarut lebih banyak.

\section{Ketinggian Busa}

Hasil sidik ragam menunjukkan bahwa perlakuan jenis pelarut, ukuran partikel bahan dan interaksi antar perlakuan berpengaruh sangat nyata $(\mathrm{P}<0,01)$ terhadap ketinggian busa ekstrak kasar saponin daun bidara. Nilai rata-rata ketinggian busa ekstrak kasar saponin dapat dilihat pada Tabel 3.

Tabel 3. Nilai rata-rata ketinggian busa (mm)

\begin{tabular}{lccc}
\hline \multirow{2}{*}{ Jenis Pelarut (P) } & \multicolumn{3}{c}{ Ukuran Partikel (S) } \\
\cline { 2 - 4 } & S1 $(40$ mesh) & S2 $(60$ mesh) & S3 $(80$ mesh) \\
\hline P1 (Metanol) & $7,21 \pm 0,02^{\mathrm{c}}$ & $7,52 \pm 0,01^{\mathrm{b}}$ & $8,27 \pm 0,01^{\mathrm{a}}$ \\
P2 (Etanol) & $6,06 \pm 0,02^{\mathrm{f}}$ & $6,30 \pm 0,03^{\mathrm{e}}$ & $6,48 \pm 0,04^{\mathrm{d}}$ \\
P3 (Aseton) & $4,08 \pm 0,07^{\mathrm{i}}$ & $4,44 \pm 0,06^{\mathrm{h}}$ & $5,47 \pm 0,02^{\mathrm{g}}$ \\
\hline
\end{tabular}

Keterangan : Huruf berbeda di belakang nilai rata-rata menunjukkan perbedaan yang sangat nyata pada taraf kesalahan $1 \%(\mathrm{P}<0,01)$.

Tabel 3 menunjukkan bahwa jenis pelarut metanol dengan ukuran partikel bahan 80 mesh menghasilkan rata-rata ketinggian busa tertinggi yaitu sebesar $8,27 \pm 0,01 \mathrm{~mm}$ sedangkan jenis pelarut aseton dengan ukuran partikel 40 mesh menghasilkan rata-rata ketinggian busa terendah yaitu sebesar 4,08 $\pm 0,07 \mathrm{~mm}$. Hal ini menunjukkan bahwa semakin polar pelarut yang digunakan dan semakin kecil ukuran partikel bahan, maka semakin tinggi busa yang dihasilkan. Hal tersebut dikarenakan tinggi busa yang terbentuk dipengaruhi oleh kadar saponin yang terkandung pada sampel. Semakin tinggi kadar saponin yang dihasilkan maka semakin tinggi busa yang terbentuk. Hal ini sesuai dengan penelitian yang dilakukan bahwa kadar saponin tertinggi terdapat pada perlakuan jenis pelarut metanol dengan ukuran partikel 80 mesh yaitu sebesar $20,40 \pm 0,79$ persen sedangkan kadar saponin terendah terdapat pada perlakuan jenis pelarut aseton dengan ukuran partikel bahan

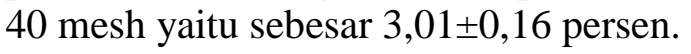

Sesuai dengan pernyataan Ariani (2013) menyatakan bahwa semakin tinggi busa yang terbentuk setelah penggojogkan dan penambahan $\mathrm{HCl} 2 \mathrm{~N}$ maka semakin tinggi kadar saponin yang terkandung pada sampel. Terbentuknya busa setelah 
penambahan $\mathrm{HCl} 2 \mathrm{~N}$ dikarenakan jembatan glikosida yang menghubungkan glikon dan aglikon sangat mudah terurai oleh pengaruh asam, basa, air, enzim dan panas. Apabila kadar asam dan basa semakin pekat maupun suhu lingkungan semakin panas, maka glikosida akan semakin cepat terhidrolisis Octaviani (2009). Hal ini sesuai dengan penelitian yang telah dilakukan bahwa dengan penambahan $\mathrm{HCl} 2 \mathrm{~N}$ yang bersifat asam menyebabkan senyawa glikosida terhidrolisis sehingga mengakibatkan terbentuknya buih yang stabil. Kemampuan saponin membentuk buih dikarenakan kombinasi struktur senyawa penyusunnya yaitu rantai gula yang bersifat hidrofilik (larut dalam air) dan bagian rantai sapogenin yang bersifat hidrofobik (larut dalam lemak) (Jaya, 2010).

Berdasarkan ketiga variabel yang diamati dapat ditentukan perlakuan terbaik dari sembilan kombinasi perlakuan di atas. Hasil yang diperoleh menunjukkan bahwa perlakuan jenis pelarut metanol dengan ukuran partikel 80 mesh merupakan perlakuan terbaik untuk menghasilkan ekstrak daun bidara sebagai sumber saponin. Hal ini dikarenakan perlakuan tersebut menghasilkan nilai tertinggi pada karakteristik rendemen, kadar ekstrak saponin kasar dan ketinggian busa daun bidara.

\section{KESIMPULAN DAN SARAN}

\section{Kesimpulan}

Berdasarkan hasil penelitian yang telah dilakukan dapat disimpulkan, antara lain :

1. Perlakuan jenis pelarut dan ukuran partikel bahan sangat berpengaruh terhadap rendemen, kadar ekstrak saponin kasar dan ketinggian busa daun bidara sebagai sumber saponin. Interaksi antar perlakuan sangat berpengaruh terhadap rendemen dan ketinggian busa.
Namun, berpengaruh nyata terhadap kadar ekstrak saponin kasar daun bidara.

2. Perlakuan jenis pelarut metanol dengan ukuran partikel bahan 80 mesh merupakan perlakuan terbaik untuk menghasilkan ekstrak daun bidara sebagai sumber saponin dengan nilai rendemen sebesar 17,91 $\pm 0,73 \%$, kadar saponin kasar $20,40 \pm 0,79 \%$ dan ketinggian busa sebesar 8,27 $\pm 0,01 \mathrm{~mm}$.

\section{Saran}

Berdasarkan hasil penelitian ini dapat disarankan beberapa hal sebagai berikut :

1. Berdasarkan hasil penelitian yang telah dilakukan, untuk menghasilkan ekstrak saponin daun bidara (Ziziphus mauritiana L.) terbaik disarankan menggunakan jenis pelarut metanol dan ukuran partikel bahan 80 mesh.

2. Perlu dilakukan penelitian lebih lanjut mengenai analisa kadar saponin daun bidara dengan metode lain sehingga ekstrak saponin yang dihasilkan dapat diaplikasikan sebagai bahan pembusa sabun.

\section{DAFTAR PUSTAKA}

Antari, N.M.R.O. 2015. Pengaruh ukuran partikel dan lama ekstraksi terhadap karakteristik ekstrak warna alami buah pandan (Pandanus tectorius). Jurnal Rekayasa dan Manajemen Agroindustri. 3(4): 30-40.

AOAC. 1999. Official Methods of Analysis (15th). K. Helrich (Ed.). Virginia.

Ariani, A. 2013. Saponin akasia (Acacia auriculiformis A.cunn) sebagai pembusa alami dan agensia antibakteri dalam sabun cair. Skripsi. Tidak dipublikasi. Jurusan Kimia, Fakultas Sains dan Matematika, Universitas Kristen Satya Wacana, Salatiga. 
Bintoro, A., A.M. Ibrahim dan B. Situmeang. 2017. Analisis dan identifikasi senyawa saponin dari daun bidara (Zhizipus mauritania L.). Jurnal Itekima. 2(1): 8494.

Calabria, L.M. 2008. The Isolation and Characterization of Triterpene Saponins from Silphium and the Shemosystematic and Biological Significance of Saponins in the Asteraceae. Disertasi. Tidak dipublikasi. University of Texas, Austin.

Chen, Y.L., E.W.L. Chan, P.L. Tan, Y.Y. Lim, J. Stanslas and J.K. Goh. 2010. Assessment of phytochemical content, pholyphenolic composition, antioxidant and antibacterial activities of Leguminosae medicinal plants in peninsular Malaysia. BMC Complementary and Alternative Medicine. 11(12): 2-10.

Darma, G., Lucyana dan H.G. Pohan. 1991. Pengaruh jenis pelarut serta ukuran partikel terhadap rendemen dan kadar piperin oleoresin limbah lada putih (Piper nigrum Linn). Journal of Agrobased Industry. 5(1): 24-27.

Farnsworth, N.R. 1966. Biological and phytochemical screening of plants. Journal of Pharmaceutical Sciences. 5(3): 225-276.

Gillespie, R.J. and Paul. 2001. Chemical Bonding and Molecular Geometry. Oxford University Press, Oxford.

Harborne, J.B. 1987. Metode Fitokimia Penuntun Cara Modern Menganalisis Tumbuhan. Edisi II. Terjemahan Kosasih Padmawinata dan Iwang Soediro (Eds.). Penerbit ITB, Bandung.

Hardiningtyas, S.D. 2009. Aktivitas Antibakteri Ekstrak Karang Lunak Sarcophyton sp. yang Difragmentasi dan Tidak Difragmentasi di Perairan Pulau Pramuka, Kepulauan Seribu. Skripsi. Tidak dipublikasi. Fakultas Matematika dan Ilmu Pengetahuan Alam, Institut Pertanian Bogor.

Heyne, K. 1987. Tumbuhan Berguna Indonesia, Jilid III. Yayasan Sarana Wanaraja, Jakarta.

Jaya, A.M. 2010. Isolasi dan Uji Efektivitas Antibakteri Senyawa Saponin dari Akar Putri Malu (Mimosa pudica). Skripsi. Tidak dipublikasi. Jurusan Kimia, Fakultas Sains dan Teknologi, Universitas Islam Negeri Maulana Malik Ibrahim, Malang.

Ketaren, S. 1986. Pengantar Teknologi Minyak dan Lemak Pangan. Universitas Indonesia Press, Jakarta.

Mandal, P. 2005. Antimicrobial activity of saponins from Acacia auriculiformis. Fitoterapia. 76(5): 462-465.

Manoi, F. 2015. Pengaruh kehalusan bahan dan lama ekstraksi terhadap mutu ekstrak tempuyung (Sonchus arvensis L.). Jurnal Penelitian Pertanian Terapan. 15(2): 156-161.

Michel, G.C., D.I. Nesseem and M.F. Ismail. 2011. Antidiabetik activity and stability study of the formulated leaf extract of Ziziphus spina-christi with the influence of seasonal variation. Journal of Ethnopharmacology. 133(1): 53-62.

Mien, D.J., W.A. Carolin dan P.A. Firhani. 2015. Penetapan kadar saponin pada ekstrak daun lidah mertua (Sansevieria trifasciata Prain varietas S. Laurentii) secara gravimetri. Jurnal Ilmu dan Teknologi Kesehatan. 2(2): 65-69.

Ngo, T.V., C.J. Scarlett, M.C. Bowyer, P.D. Ngo and Q.V. Vuong. 2017. Impact of Different Extraction Solvents on Bioactive Compounds and Antioxidant Capacity from the Root of Salacia 
chinensis L. Journal of Food Quality. 2017(-): 1-8.

Novitasari, A.E. dan D.Z. Putri. 2016. Isolasi dan identifikasi saponin pada ekstrak daun mahkota dewa dengan ekstraksi maserasi. Jurnal Sains. 6(12): 10-14.

Octaviani, Y. 2009. Isolasi dan Identifikasi Aglikon Saponin Kecambah Kacang Hijau (Phaseolus radiates L.). Skripsi. Tidak dipublikasi. Fakultas Farmasi, Universitas Sanata Dharma, Yogyakarta.

Pasaribu, T., D.A. Astuti, E. Wina, Sumiati and A. Setiyono. 2014. Saponin content of Sapindus rarak Pericarp affected by particle size and type of solvent, its biological activity on Eimeria tenella Oocysts. Journal of Poultry Science. 13(6): 347-352.

Pham, H.N.T., V.T. Nguyen, Q.V. Vuong, M.C. Bowyer and C.J. Scarlett. 2015. Effect of extraction solvents and drying methods on the physicochemical and antioxidant properties of Helicteres hirsuta L. Technologies. 3(-): 285-301.

Pratiwi, E. 2010. Perbandingan Metode Maserasi, Remaserasi, Perkolasi dan Reperkolasi dalam Ekstrak Senyawa Aktif Andrographolide dari Tanaman Sambiloto (Andrographis paniculata N.). Skripsi. Tidak dipublikasi. Fakultas Teknologi Pertanian, Institut Pertanian Bogor, Bogor.

Safrudin, N. dan F. Nurfitasari. 2018. Analisis senyawa metabolit sekunder dan uji aktivitas antioksidan dengan metode DPPH (1,1-diphenyl-2picrylhydrazyl) dari ekstrak daun bidara (Ziziphus spina-christi L.). Jurnal Itekima. 4(2): 11-20.
Sen, C., H.P.S. Makkar and K. Becker. 1998. Alfalfa saponins and their implication in animal nutrition. Journal Agriculture Food Chem. 46(1): 131-140.

Sudarmadji, S., B. Haryono dan Suhardi. 1997. Analisa Bahan Makanan dan Pertanian. Penerbit Liberty, Yogyakarta.

Suharto, M.A.P., H.J. Edy dan J.M. Dumanauw. 2012 Isolasi dan identifikasi senyawa saponin dari ekstrak metanol batang pisang ambon (Musa paradisiaca var. sapientum L.). Pharmacon. 1(2): 86-92.

Vincken, J.P., L. Heng, A.D. Groot and H. Gruppen. 2007. Saponnins, classification and occurrence in the plant kingdom. Journal Phytochemistry. 68(-): 275-297.

Vogel, A.I. 1978. Kimia Analisa Kuantitatif Anorganik. EGC, Jakarta.

Yulianingtyas, A. dan B. Kusmartono. 2016. Optimasi volume pelarut dan waktu maserasi pengambilan flavonoid daun belimbing wuluh (Averrhoa bilimbi L.). Jurnal Teknik Kimia. 10(2): 58-64. 